\title{
Pedagogic organization of part-time studies in Network and Telecommunications at the bachelor level
}

\author{
Alain MORAND \\ Univ. Grenoble Alpes, \\ IUT 1 Dépt. RT, \\ BP 67, 38042 Saint Martin d'Hères cedex, France
}

\author{
Jean-Marc THIRIET \\ Univ. Grenoble Alpes, \\ IUT 1 Dépt. RT, \\ BP 67, 38042 Saint Martin d'Hères cedex, France
}

\begin{abstract}
This paper develops two aspects. For international colleagues, it explains the way it is possible to finance some students and academic programmes in partnership with companies in France. The second aspect deals with the pedagogic adaptations of classes of students organized around sandwich part-time studies. This organization takes account of the required competences for the students.
\end{abstract}

Keywords-sandwich part-time studies, pedagogical organisation, policy

\section{INTRODUCTION}

The present paper aims at presenting the system existing in France, allowing some students to follow part-time studies, with the purpose of professional insertion. Professional organizations as well as territorial collectivities are parts of the economic model. This possibility is also a way to attract more students to higher education and in our fields, taking account of the possibility for the student to be payed during her/his education/training, it is one possible tool for the "social lift". One of the deals, from the point of view of the French government, is to increase the number of people educated at the bachelor level, taking account of the fact there are jobs in our field at this level. The double objective of the government is so to increase the number of students at the bachelor level, with a possibility of professional insertion at this level, and also not to have every student at the master level.

In this paper, we focus on the DUT (Diplôme Universitaire de Technologie) and Professional Bachelor, which give the possibility to reach the professional world at the bachelor level.

The second section reminds how the academic studies are organized in France, especially the DUT and Prof. Bachelor. The third section explains the way sandwich or parttime studies can be financed in France. In the $4^{\text {th }}$ section, we discuss the pedagogical organization of these part-time classes in our institution, and the $5^{\text {th }}$ section gives some feedbacks from more than 10 years of experience.

\section{NETWORK AND TELECOMMUNICATION DEPARTMENT IN IUT} [1]:

In France, there are several kinds of academic institutions

- Universities, which propose Classical curricula (Bachelor, 3 years, followed by Master, 2 years) and Professional curricula (DUT, 2 years + "licence professionnelle", this is just the $3^{\text {rd }}$ year after the 2 first years of DUT for instance). There are possibilities for the students to switch from the classical to the professional curricula more or less at each level.

- Graduate schools of engineering which prepare engineering graduation ("Diplôme d'Ingénieur"); the Master grade is automatically associated with this degree.

In this paper we will focus on DUT and Professional Bachelor. DUT ("Diplôme Universitaire de Technologie") is a national degree in France (the only academic programme having a national programme in France, the other academic programmes are specific to each university, due to the autonomy of universities). Professional Bachelor is so the $3^{\text {rd }}$ year programme, with different contents depending on the university policies.

In IUTs ("Institut Universitaire de Technologie") in France, there are Departments representative of specialities. Networks and Telecommunications (RT, Réseaux et Télécommunications) is the speciality we are involved in [2]. Networks and Telecommunications is a speciality which was first created in Nancy in 1991. In Grenoble, such a speciality was launched officially in 1998.

\section{ALTERNATING PROFESSIONAL}

In France, it is possible now to follow sandwich training, mixing theoretical, practice and company work in an alternative way. The interest is to acquire a professional experience recognized by a degree in the university and a professional certification. There are two types of possible contracts for students [3, 4]: the "professional training contract" and the "apprenticeship contract". They differ from different criteria as the concerned people, the contract period, the training time part, the salary for the student, the funding 
for the training and also taxes exemption given to the employer.

\section{A. Apprenticeship contract:}

The objective of this contract is to clearly follow a classical training proposed for example by the university and to have in parallel a professional experience. At the end of the training, the student must access to a degree level. The concerned people is essentially person being between 16 and 25 years of age which correspond to IUT audience. The contract period from 1 to 3 years depends on the training level prepared. A training period minimum of 400 hours by year is required in the university to teach different fields: general education as communication, management and law application. Theoretical and practical parts are proposed to give brick basis to the student in order to increase his autonomy in the company with an attendance in the company of almost $50 \%$. The wage depends on the age of the person and the level of the degree prepared as shown in the Table I.

TABLE I. MINIMUM FUNDING FOR AN APPRENTICESHIP CONTRACT

\begin{tabular}{|l|l|c|c|}
\hline & $16 / 17$ years old & $\mathbf{1 8 / 2 0}$ years old & $\begin{array}{c}\text { 21 years old and } \\
\text { more }\end{array}$ \\
\hline $\begin{array}{l}\text { First } \\
\text { degree } \\
\text { level }\end{array}$ & $25 \%$ of SMIC & $41 \%$ of SMIC & $53 \%$ of SMIC \\
\hline $\begin{array}{l}\text { Second } \\
\text { degree } \\
\text { level }\end{array}$ & $37 \%$ of SMIC & $49 \%$ of SMIC & $61 \%$ of SMIC \\
\hline $\begin{array}{l}\text { Third } \\
\text { degree } \\
\text { level }\end{array}$ & $53 \%$ of SMIC & $65 \%$ of SMIC & $78 \%$ of SMIC \\
\hline
\end{tabular}

SMIC (French minimum wage): 1153 euros net / month.

Commonly, public sector companies recruit apprentices. The person employed working 35 hours a week in the company but also at the university. And the fixed-term contract is made to protect the employee from economic difficulties of the company during the contract period. For only the first 45 days accomplished in the company, his contract can be interrupted.

\section{B. Professionnal contract:}

There are miscellaneous objectives: it can be used to complete an initial training. It can also give access to a qualification certificate recognized by the professional domain [5] in which the company is associated as UDIMEC [6] for example in France relied to the metal industry sector. It can also be proposed to jobseeker reinsertion or to qualify an employee inside its company. For example, an employee is recruited with a basic degree level. And after a few-year experience, he has enlarged the number and the level of his tasks which is reserved normally to a more qualified employee. The professional contract is a solution in this case to offer to the employee the possibility to reach the requested level. The concerned people are person being between 16 and 25 years of age as the apprentice contract but also jobseeker aged 26 and older and a person having a single insertion contract (CUI) which is a process to help a professional insertion. The contract period can be between 6 to 12 months and can be extend to 24 months under specific conditions. The training period is between $15 \%$ and $25 \%$ of the total contract period but without reaching a minimum equals to $150 \mathrm{~h}$. The alternative work shared with the training organism and the company is required. And an important specificity is to accomplish the major tasks relied to the skills defended in the professional certificate prepared in parallel. The wage depends as the apprentice contract to the age of the person but also to the last degree level obtained as shown in the Table II and the industrial branch of the company.

TABLE II. MINIMUM FUNDING FOR A PROFESSIONAL CONTRACT

\begin{tabular}{|c|c|c|c|}
\hline ANY COMPANY & $\begin{array}{c}16 / 20 \text { years } \\
\text { old }\end{array}$ & $\begin{array}{c}21 / 25 \text { years } \\
\text { old }\end{array}$ & $\begin{array}{l}26 \text { years old } \\
\text { and more }\end{array}$ \\
\hline $\begin{array}{l}\text { Without a } \\
\text { Professional high } \\
\text { school diploma }\end{array}$ & $55 \%$ of SMIC & $70 \%$ of SMIC & $\begin{array}{c}100 \% \text { of } \\
\text { SMIC }\end{array}$ \\
\hline $\begin{array}{l}\text { With a } \\
\text { Professional high } \\
\text { school diploma }\end{array}$ & $65 \%$ of SMIC & $80 \%$ of SMIC & $\begin{array}{c}100 \% \text { of } \\
\text { SMIC }\end{array}$ \\
\hline $\begin{array}{l}\text { COMPANY } \\
\text { RELIED TO } \\
\text { UDIMEC (as an } \\
\text { example) }\end{array}$ & $\begin{array}{c}16 / 20 \text { years } \\
\text { old }\end{array}$ & $\begin{array}{c}21 / 25 \text { years } \\
\text { old }\end{array}$ & $\begin{array}{c}26 \text { years old } \\
\text { and more }\end{array}$ \\
\hline $\begin{array}{l}\text { Without a } \\
\text { Professional high } \\
\text { school diploma }\end{array}$ & $60 \%$ of SMIC & $75 \%$ of SMIC & $\begin{array}{c}100 \% \text { of } \\
\text { SMIC }\end{array}$ \\
\hline $\begin{array}{l}\text { With a } \\
\text { Professional high } \\
\text { school diploma }\end{array}$ & $70 \%$ of SMIC & $85 \%$ of SMIC & $\begin{array}{c}100 \% \text { of } \\
\text { SMIC }\end{array}$ \\
\hline
\end{tabular}

It is allowed to realize this contract in the university with or without the qualification certificate preparation. Nevertheless, if it is the case, the student is going to pass independently a bachelor degree and a certificate. The first corresponding to the university and the second corresponding to professional skills defended in front of a professional jury.

\section{Alternating TRAINING INT THE IUT (DUT AND BACHELOR DEGREE)}

In order to welcome part-time students, we have, as a pedagogical team, to organize their classes. This is what we discuss in this section.

In our Department, we have around 95 students in the first year-DUT, 82 second year DUT-students among whom 25 are in sandwich studies and 46 students in the professional bachelor class $\left(3^{\text {rd }}\right.$ year) among whom 20 are in the sandwich class.

It means that we have one group of students in the second year and one in the third year, as part-time students. These students come at the university around every one week of two. Depending on the actual pedagogical content of the semesters, it can be a little bit more time in the company or a little bit more in the university. Because of their calendar, these students are never mixed with others, everything is organized for them only (courses, labs, other pedagogical activities). When they are at the university, they have a 35-hour per week activity 
(flowing their industrial contract) which means that the week is quite loaded with classes. Of course, when they are in the company, there is no class for them. The content of classical courses and labs is the same as classical students, in order for them to reach the same level of knowledge. Classical students have some activities like "academic projects" which is a project which should be managed by groups of students, autonomously, these projects are organized at the university for the classical students.

For part-time students, their projects should be managed within the company. This is an important aspect, which means that when negotiating with the company, the agreement is signed by the student, the company and the university and the academic dimension aims at checking that the student will reach a certain level of competences in the technical field and some transversal competences (team working, communication, project management...) in the company, the important point is that the content in the company is discussed... Based on this competence analysis, it is possible to make a good balance between the competences got during the academic classes and the competences got during the professional experience, both contributing for the students to pass at the end the same level of exam as a classical student.

As it was explained in the previous part, a tool is proposed by professional societies (CQP) with some standardized competence accreditation processes.. We use them, together with companies. We have also, thanks to this part-time proposition, the possibility to attract other student profiles, less academically-oriented, coming from technical "baccalauréat" (end of the second degree).

We work also for the professional Bachelor group with a training partner "Pole formation des industries technologiques de l'Isère" in relation with UDIMEC. The CQP can be proposed to our student thanks by this partner. So in this way, it manages the CQP part, controlling the written document before sending it to UDIMEC and defining the jury for the oral defense. It helps us to commercialize also the sandwich training in front of second year students and manages also the professional contract with the company. Their favour relation with specific companies can attrack also other people interested by professional contract as persons already employed and looking for a reevaluation of their diploma. And this context, we can find together specific training solutions to give easier the integration of this kind of person in the 3 year bachelor group. For example, we can propose short block trainings before beginning the bachelor giving requested basis in mathematical, telecommunication or networks.

\section{PRACTICAL FEEDBACK}

The schedule of the alternating persons must be defined in advance and our difficulty is to insert this schedule in the classical university schedule concerning a lot of different speakers: teachers, associate professors, part-time teachers ... And a second difficulty, to reduce the training cost, is to try to regroup alternating persons and classical students to follow tutorial classes together. Only lab works are separated for the professional bachelor group. For the DUT group, all the courses are separated. So in general, the schedule is very few modified during the year. For the alternating people, as they are employed by the company, we must respect a specific hour number of work during the week which is $35 \mathrm{~h}$ the week. To have a small flexibility, sometimes it is necessary to add some autonomous session of $1 \mathrm{~h}$ depending on the availability of the professors and the lab rooms. As two alternating groups (bachelor degree and second year of the DUT) are proposed in our university, the schedule of each group is made in order to have practically only one group by week during the university training in order not to saturate some network or telecommunication lab rooms. To respect the requirements of the professional bachelor criteria, some professional speakers are selected to do the theoretical and lab training. This part is around $20 \%$ of the courses. This is a guaranty to have a training program closely linked to the skills required in industry. There is also an important reporting of the student opinion in order to analyse rapidly some difficulties during the training (overload of trainings, lack of interest for specific modules, difficulties for few persons to follow a training, graded problems ..). For example, this year some students coming from BTS (Brevet de Technicien Supérieur) had not enough telecommunication knowledge inducing difficulties to follow this training. This problem can appear when a lot of people come from different programmes (BTS, classical bachelor, other speciality...). To improve that, we propose supplementary hours to adapt these persons to the required level.

During their training year, our students must prepare a qualification certificate (CQP). And this is an important work for them which is done when they are in the company. A small course is done to explain the objective and the process to follow in order to complete the document which is written. This document is send to the organization managing the collective agreement chosen, which is UDIMEC in our case, in order to be validated. They must explain their role in the company and the abilities acquired or which will be acquired during this year. The evaluation is a validation or not attributing a certificate thanks by a written document and an oral defense. This validation is independent of the university diploma defended in parallel. And sometimes, our student are not enough motivated to have this certificate. So we add a supplementary grade in the university training taking in account this work with a ponderation equivalent to the professional experience.

\section{CONCLUSION}

This paper shows the possibility we have in France to finance some students using "contrats de professionalisation" and "contrats d'apprentissage". These contacts are co-financed by local collectivities and/or professional societies. The general purpose is to attract on our professional programmes students who are less attracted by classical studies, taking account of the fact that there are many jobs in the field, at the bachelor level. The knowledge is the same, the competences are equivalent, but the modalities (part-time in company, the students being payed) allow to develop or increase motivation for some students. In the same time, our department gets some money from these contracts, it is useful particularly to update regularly the software and hardware used in the Department. 
One of our purpose is to see how we can manage, within the frame of a European project, to transfer the model at the European level, within the frame for instance of a partnership between companies and universities.

\section{REFERENCES}

[1] Under the co-ordination of M.J. MARTINS \& J.M. THIRIET. "Overview of the Bologna Process - Implementation in Europe in Electrical and Information Engineering", Nancy-Grenoble, September 2008, 538 pages, (ISBN - 2-9516740-3-1). http://www.eiesurveyor.org/cd/documents/Bologna_Process/Bologna_Process.pdf
[2] JM THIRIET, D LUBINEAU, H YAHOUI. "International exchanges and double diplomas with several partners: experience feedbacks in Grenoble with a bachelor in wireless networks and security". $24^{\text {th }}$ annual EAEEIE Conference, Chania, Greece, 30-31 May 2013, pp.52-56, ISBN 978-1-4799-0042-8, DOI 10.1109/EAEEIE.2013.6576501

[3] http://travail-emploi.gouv.fr/formation-professionnelle/formation-enalternance/

[4] https://ec.europa.eu/epale/en/blog/french-forms-contract-sandwichcourses

[5] https://en.wikipedia.org/wiki/Collective_agreement

[6] https://www.udimec.fr/ 